\title{
Article
}

\section{Characterization of a Yellow Laccase from Botrytis cinerea 241}

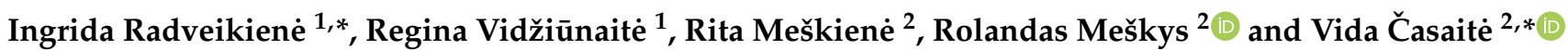 \\ 1 Life Sciences Center, Department of Bioanalysis, Institute of Biochemistry, Vilnius University, \\ Sauletekio Ave. 7, 10257 Vilnius, Lithuania; regina.vidziunaite@bchi.vu.lt \\ 2 Life Sciences Center, Department of Molecular Microbiology and Biotechnology, Institute of Biochemistry, \\ Vilnius University, Sauletekio Ave. 7, 10257 Vilnius, Lithuania; rita.meskiene@bchi.vu.lt (R.M.); \\ rolandas.meskys@bchi.vu.lt (R.M.) \\ * Correspondence: ingrida.jurkeviciute@gmc.vu.lt (I.R.); vida.casaite@bchi.vu.lt (V.Č.)
}

Citation: Radveikienè, I.;

Vidžiūnaitè, R.; Meškienè, R.; Meškys, R.; Časaitè, V. Characterization of a Yellow Laccase from Botrytis cinerea 241. J. Fungi 2021, 7, 143 https://doi.org/10.3390/jof7020143

Academic Editor: Craig Faulds

Received: 11 January 2021

Accepted: 14 February 2021

Published: 17 February 2021

Publisher's Note: MDPI stays neutral with regard to jurisdictional claims in published maps and institutional affiliations.

Copyright: (c) 2021 by the authors. Licensee MDPI, Basel, Switzerland. This article is an open access article distributed under the terms and conditions of the Creative Commons Attribution (CC BY) license (https:// creativecommons.org/licenses/by/ $4.0 /)$.

\begin{abstract}
Typical laccases have four copper atoms, which form three different copper centers, of which the T1 copper is responsible for the blue color of the enzyme and gives it a characteristic absorbance around $610 \mathrm{~nm}$. Several laccases have unusual spectral properties and are referred to as yellow or white laccases. Only two yellow laccases from the Ascomycota phylum have been described previously, and only one amino acid sequence of those enzymes is available. A yellow laccase Bcl1 from Botrytis cinerea strain 241 has been identified, purified and characterized in this work. The enzyme appears to be a dimer with a molecular mass of $186 \mathrm{kDa}$. The gene encoding the Bcl1 protein has been cloned, and the sequence analysis shows that the yellow laccase Bcl1 is phylogenetically distinct from other known yellow laccases. In addition, a comparison of amino acid sequences, and 3D modeling shows that the Bcl1 laccase lacks a conservative tyrosine, which is responsible for absorption quenching at $610 \mathrm{~nm}$ in another yellow asco-laccase from Sclerotinia sclerotiorum. High thermostability, high salt tolerance, broad substrate specificity, and the ability to decolorize dyes without the mediators suggest that the Bcl1 laccase is a potential enzyme for various industrial applications.
\end{abstract}

Keywords: yellow laccase; Botrytis cinerea; biocatalysis; dye decolorization

\section{Introduction}

Laccases (benzenediol: oxygen oxidoreductase; E.C. 1.10.3.2) oxidize a great variety of aromatic compounds [1,2]. They can be applied for wide industrial applications: organic synthesis, biosensor construction, biofuel cells development, biomass valorization, and xenobiotic biodegradation [3-12]. Typical laccases have four copper atoms, which form three different copper centers (type T1, T2 and T3) [13,14]. The T1 copper is responsible for the blue color of the enzyme and gives it a characteristic absorbance around $610 \mathrm{~nm}$ [15-17]. However, several laccases have unusual spectral properties. These enzymes are referred to as "yellow" or "white" laccases [13,18]. Some fungi, such as Panus tigrinus, Phlebia radiata, and Phlebia tremellosa [18], Stropharia aeruginosa [19], Ganoderma fornicatum [20], Pleurotus ostreatus [21], Leucoagaricus naucinus [22], Daedalea flavida [23], Trametes sp. F1635 [24] and Sclerotinia sclerotiorum [25] produces yellow laccases. The features of the T1 copper site in yellow or white laccases are missing in their spectra. Different metal ions in active site (such as iron [26] or zinc and iron [27]), incomplete oxidation state of copper [26] or altered copper coordination sphere [28] are associated with the form of white laccase.

Leontievsky and co-authors showed that yellow laccase occurs upon binding of a low molecular mass phenolic compound. Subsequently Mot and co-authors identified the binding site- the compound covalently binds to the tyrosine residue site at the T1 center and turns laccase from blue to yellow [18,29]. Yellow laccases outperform blue laccases, with improved catalytic properties as well as the ability to oxidize some substrates (e.g., nonphenolic part of lignin) without mediators, making them attractive biocatalysts [30,31]. 
The diversity and catalytic properties of these laccases including ones from Botrytis cinerea (teleomorphic form: Botryotinia fuckeliana) ascomycetes are still scarcely investigated. Usually, each Botrytis spp. strain can produce several laccase isoenzymes of rather different physico-chemical features [32-38]. Such abundance of laccases produced by these fungi is not surprising, as 15 genes encoding laccases have been identified in the genome of $B$. cinerea $[39,40]$. Laccases produced by this phytopathogen, which infects at least 1400 plant species, is presumably related to detoxification of defense metabolites produced by the plant. B. cinerea laccases destruct plants and impacts phenolic composition and quality of must and wine [41-43], however, yellow laccase from $B$. cinerea has not been known so far.

In this study, we purified a yellow laccase Bcl1 of B. cinerea 241, identified the Bcl1 protein encoding gene and compared the protein properties with other yellow laccases. In addition, we presented data on biochemical and catalytic properties of the Bcll enzyme including the de-colorization of some synthetic dyes.

\section{Materials and Methods}

\subsection{Materials}

2,2'-azino-bis(3-ethylbenzothiazoline-6-sulfonic acid) diammonium salt (ABTS), promazine hydrochloride, syringaldazine, 1-naphthol, 2-naphthol, vanillin, galangin, kaempferol, myricetin, quercetin, fisetin, gallic, syringic, synapic, cinnamic, vanillic, chlorogenic acids, veratryl alcohol, L-3,4-dihydroxyphenylalanine (L-dopa), metal salts, and hydrogen peroxide were purchased from Sigma-Aldrich, Buchs, Switzerland. Methyl syringate purchased from Lancaster Synthesis, Ward Hill, MA, USA, was additionally recrystallized from ethanol. 2,6-dimethoxyphenol was obtained from Alfa Aesar, Kandel, Germany. Methanol, $p$-coumaric, $o$-coumaric, $m$-coumaric, ferulic, and caffeic acids were obtained from Fluka, Steinheim, Switzerland. $N, N^{\prime}$-dimethylamine-4-(4-morpholine)benzene, $3-(10 H$-phenoxazin-10-yl)propanoic acid and 2-(10H-phenoxazin-10-yl)ethanol were prepared as described [44]. Catechol, hydroquinone, $p$-phenylenediamine, potassium hexacyanoferrate (II), and dyes were obtained from Reachim, Moscow, Russia. Molecular biology enzymes and kits were purchased from Thermo Fisher Scientific, Vilnius, Lithuania.

\subsection{Media and Culture Conditions}

The fungal strains were kept on malt extract agar media ( $2 \%$ of agar, $2 \%$ of malt extract and $0.4 \%$ of yeast extract). The pre-culture medium consisted of $\left(\mathrm{g} \mathrm{L}^{-1}\right)$ : malt extract-3.5, yeast extract-2.5, $\mathrm{MgSO}_{4}-0.5$, glucose-8.0, $\mathrm{KH}_{2} \mathrm{PO}_{4}-2.0$, $\mathrm{pH}$ 5.0. SSL1 medium consisted of $\left(\mathrm{g} \mathrm{L}^{-1}\right)$ : malt extract-5.0, vegetable peptone-10.0, $\mathrm{MgSO}_{4}-0.1$, $\mathrm{pH}$ 5.2. $\mathrm{CuSO}_{4}(1.5 \mathrm{mM})$ and $\mathrm{H}_{3} \mathrm{PO}_{4}(1.0 \mathrm{mM})$ were added after sterilization. SSL2 medium consisted of $\left(\mathrm{g} \mathrm{L}^{-1}\right)$ malt extract-3.5, yeast extract-2.5, $\mathrm{KH}_{2} \mathrm{PO}_{4}-20.0, \mathrm{MgSO}_{4}-0.5$, $\mathrm{pH}$ 5.5. $\mathrm{CuSO}_{4}(6.0 \mathrm{mM})$ was added after sterilization.

The mycelia of fungi taken from spoiled raspberries fruits were placed in sterile distilled water, mixed for $2 \mathrm{~min}$ and the aliquots were spread on a solid medium supplemented with ABTS $(1 \mathrm{mM})$. The plates were incubated at $20{ }^{\circ} \mathrm{C}$ for five days. Microorganisms showing positive reaction were selected and purified by streaking repeatedly on the malt agar medium.

The liquid pre-cultures were prepared by adding $1 \mathrm{~cm}^{2}$ of fungal culture from the agar plates to the $50 \mathrm{~mL}$ of pre-culture medium and grown for 4 days at $20^{\circ} \mathrm{C}$ with agitation on the rotary shaker. The Erlenmeyer flasks with $200 \mathrm{~mL}$ of medium SSL1 or SSL2 were inoculated with $8 \mathrm{~mL}$ of liquid fungal suspension and cultivated for 3 days on a rotary shaker at $180 \mathrm{rpm}$ and $20^{\circ} \mathrm{C}$.

\subsection{Purification of Laccases}

When the laccase activity had reached its production peak, the culture liquid was collected, and fungal mycelium was removed by centrifugation at $1500 \times g$ and filtration. The isoenzymes were purified using different schemes. For purification of Bcl1, $10 \mathrm{~mL}$ 
of CM Toyopearl $650 \mathrm{M}$ (ToyoSoda, Tokyo, Japan) was added to the $1 \mathrm{~L}$ of culture liquid and stirred for $4-5 \mathrm{~h}$. The sorbent was precipitated by centrifugation, washed with $2 \mathrm{mM}$ sodium citrate buffer, pH 5.5, poured to the column (C 10/40 Column, GE Healthcare, Chicago, IL, USA) and the adsorbed enzyme was eluted with 0-1.0 $\mathrm{M}\left(\mathrm{NH}_{4}\right)_{2} \mathrm{SO}_{4}$ gradient. Fractions with laccase activity were pooled, supplemented with $\left(\mathrm{NH}_{4}\right)_{2} \mathrm{SO}_{4}$ up to $1.5 \mathrm{M}$ and applied to the PHE FF (GE Healthcare, Chicago, IL, USA) column equilibrated with $2 \mathrm{mM}$ sodium citrate $1.5 \mathrm{M}\left(\mathrm{NH}_{4}\right)_{2} \mathrm{SO}_{4}$ buffer $\mathrm{pH}$ 5.5. Protein was eluted with 1.5-0 $\mathrm{M}\left(\mathrm{NH}_{4}\right)_{2} \mathrm{SO}_{4}$ gradient, fractions with laccase activity were collected, concentrated and dialyzed against $2 \mathrm{mM}$ sodium citrate buffer $\mathrm{pH}$ 5.5. For purification of Bcl2, the DEAE Toyopearl $650 \mathrm{M}$ (TojoSoda, Tokyo, Japan) was added to the clarified culture medium $(10 \mathrm{~mL} / \mathrm{L})$, stirred for $1-2 \mathrm{~h}$ and removed by centrifugation. The cleared culture liquid was concentrated by tangent ultrafiltration with $10 \mathrm{kDa}$ cut-off filter (Millipore, Burlington, MA, USA). Up to $2.2 \mathrm{M}$ of $\left(\mathrm{NH}_{4}\right)_{2} \mathrm{SO}_{4}$ was added to the crude laccase and solution was kept at $4{ }^{\circ} \mathrm{C}$ overnight. The precipitates were removed by centrifugation and clear supernatant was applied to a PHE-Sepharose FF column (GE Healthcare, Chicago, IL, USA), equilibrated with $10 \mathrm{mM}$ sodium citrate $2.2 \mathrm{M}\left(\mathrm{NH}_{4}\right)_{2} \mathrm{SO}_{4}$ buffer, $\mathrm{pH}$ 5.5. Retained laccase Bcl2 was eluted by linear gradient of 2.2-0 M ( $\left(\mathrm{NH}_{4}\right)_{2} \mathrm{SO}_{4}$ in the $10 \mathrm{mM}$ sodium citrate buffer. Fractions with laccase activity were collected, concentrated, dialyzed against the $5.0 \mathrm{mM}$ sodium citrate buffer, $\mathrm{pH} 4.6$ and applied on the Super Q Toyopearl $650 \mathrm{M}$ column (ToyoSoda, Tokyo, Japan). The laccase was eluted by $0-0.5 \mathrm{M}\left(\mathrm{NH}_{4}\right)_{2} \mathrm{SO}_{4}$ linear gradient. Fractions with laccase activity were collected, concentrated, supplemented with $2.0 \mathrm{M}\left(\mathrm{NH}_{4}\right)_{2} \mathrm{SO}_{4}$ and applied on the source PHE15 (GE Healthcare, Chicago, IL, USA) column, equilibrated with $5 \mathrm{mM}$ sodium citrate $2.0 \mathrm{M}\left(\mathrm{NH}_{4}\right)_{2} \mathrm{SO}_{4}$ buffer, $\mathrm{pH}$ 5.5. Protein was eluted with 2.0-0 $\mathrm{M}\left(\mathrm{NH}_{4}\right)_{2} \mathrm{SO}_{4}$ gradient, fractions with laccase activity were collected, concentrated and dialyzed against $2.0 \mathrm{mM}$ sodium citrate buffer $\mathrm{pH}$ 5.5. Both purified enzymes were stored at $-20{ }^{\circ} \mathrm{C}$.

\subsection{Characterization of Laccases}

The UV-vis absorption spectra of the purified laccases were determined at wavelengths between 260 and $800 \mathrm{~nm}$ at $25^{\circ} \mathrm{C}$ in a sodium acetate buffer ( $50 \mathrm{mM}, \mathrm{pH}$ 5.5) using a Nicolet evolution 300 (Thermo Electron Corporation, Waltham, MA, USA) spectrophotometer. SDS-PAGE was performed according to the method of Laemmli in $14 \%$ polyacrylamide gels by using molecular mass standards (Pierce ${ }^{\mathrm{TM}}$ Unstained Protein Molecular Weight Marker and PageRuler ${ }^{\mathrm{TM}}$ Prestained Protein Ladder, Thermo Fisher Scientific, Vilnius, Lithuania). Protein concentration was determined by the method of Lowry using bovine serum albumin as a standard [45].

The molecular mass of the purified laccase was estimated by both SDS-PAGE and size exclusion chromatography (SEC) on a SuperdexTM200 5/150 GL (GE Healthcare, Chicago, IL, USA) analytical size exclusion column. The buffer for SEC was $50 \mathrm{mM}$ Tris- $\mathrm{HCl}$ supplemented with $150 \mathrm{mM} \mathrm{NaCl}, \mathrm{pH}$ 8. The molecular mass standards were apoferritin $(443 \mathrm{kDa}), \beta$-amylase $(200 \mathrm{kDa})$, alcohol dehydrogenase $(150 \mathrm{kDa})$ and albumin $(66 \mathrm{kDa})$, provided by Sigma, Darmstadt, Germany.

For deglycosylation of laccases, $1000 \mathrm{U}$ of endoglycosidase $\mathrm{H}$ (New England BioLabs, Ipswich, MA, USA) was added to the purified protein $(2 \mu \mathrm{g})$, incubated at $37^{\circ} \mathrm{C}$ for $4 \mathrm{~h}$ and the degree of deglycosylation was assessed by SDS-PAGE.

\subsection{MS/MS Analysis}

After protein separation in SDS-PAGE gel, the laccase corresponding band was excised and subjected to de novo sequencing based on matrix-assisted laser desorption ionizationtime of flight (MALDI-TOF)/TOF mass spectrometry (MS) and subsequent computational analysis at the Proteomics Centre of the Life Sciences Center, Vilnius University (Vilnius, Lithuania). The sample was purified and the analysis of peptides was performed as described previously $[46,47]$. 


\subsection{Gene Cloning and Analysis}

B. cinerea 241 mycelium from a culture grown in liquid medium was harvested when first laccase activity could be detected (six day of cultivation), and genomic DNA and RNA were isolated using ZR Fungal/Bacterial DNA MiniPrep kit (Zymo Research, Irvine, CA, USA) and Quick-RNA Fungal/Bacterial Miniprep Kit (Zymo Research, Irvine, CA, USA), respectively. cDNA was synthesized by the Maxima H Minus First Strand cDNA Synthesis Kit and oligo dT primer. The primer set, 241LACR (5'-TTARASACCAGARTCGGTCTTGAWAT$3^{\prime}$ ) and 241LACF ( $5^{\prime}$-TTSTTSAATATTCTACTTTTRTCTTC- $3^{\prime}$ ), was designed according to $B$. cinerea hypothetical protein BofuT4_P092250.1 (CCD50266.1) and Bclcc7 (XP_001551072.1) gene sequences. The primer set and Phusion Green Hot Start High-Fidelity PCR Master Mix were used to amplify laccase genes using both the chromosomal DNA and cDNA. PCR conditions were as follows: initial denaturation step at $98^{\circ} \mathrm{C}$ for $1 \mathrm{~min}$, followed by 30 cycles each consisting of $98^{\circ} \mathrm{C}$ for $20 \mathrm{~s}, 50^{\circ} \mathrm{C}$ for $20 \mathrm{~s}$, and $72{ }^{\circ} \mathrm{C}$ for $1 \mathrm{~min}$, with the final extension at $72{ }^{\circ} \mathrm{C}$ for $5 \mathrm{~min}$. The PCR products were purified with a PCR purification kit and cloned into $\mathrm{pTZ} 57 \mathrm{R} / \mathrm{T}$ vector. E. coli $\mathrm{DH} 5 \alpha$ strain was used for transformation and resulted plasmid was sequenced in both orientations (Macrogene, Amsterdam, Netherlands).

18S rRNA encoding gene was amplified with the primers EukA (5'-AACCTGGTTGATCCTGCCAGT-3 $\left.{ }^{\prime}\right)$ and EukB (5'-GATCCWTCTGCAGGTTCACCTAC $\left.-3^{\prime}\right)$ [48]. ITS region was amplified using the primers ITS5 (5'-GGAAGTAAAAGTCGTAACA AG-3') and ITS4 (5'-TCCTCCGCTTATTGATATGC-3') [49]. The PCR condition were the same as for laccase gene cloning. The PCR products were purified and sequenced in both orientations. The nucleotide sequences were deposited in the GenBank under the accession numbers: MH333282, MT704558, MT707622.

BLAST program (https:/ /blast.ncbi.nlm.nih.gov/Blast.cgi) at the National Center for Biotechnology Information (NCBI) was used for the nucleotide sequence analysis, deduction of the amino acid sequence, and database searches [50]. The phylogenetic analysis was performed using MEGA X [51]. The 3D models of laccases were constructed as previously [29] by the use of (PS) ${ }^{2}$-v2: Protein Structure Prediction Server (http:/ / ps2 .life.nctu.edu.tw/) [52] using the Melanocarpus albomyces laccase 3D structure (pdb code 2Q9O) as template by automatic selection. The 3D structures were compared and visualized by using UCSF Chimera [53].

\subsection{Enzyme Activity Assays}

Routinely, activity of laccase was determined spectrophotometrically using ABTS as a substrate. The $1 \mathrm{~mL}$ of reaction mixture consisted of $50 \mathrm{mM}$ sodium acetate buffer, $\mathrm{pH}$ 3.0, $0.1 \mathrm{mM}$ ABTS and $5 \mu \mathrm{L}(0.01-0.1 \mathrm{U})$ of laccase. The ABTS oxidation was monitored by the increase of absorbance at $420 \mathrm{~nm}\left(\varepsilon=36000 \mathrm{M}^{-1} \mathrm{~cm}^{-1}\right)$ at $25^{\circ} \mathrm{C}$. One unit of enzyme was defined as amount of enzyme that oxidized $1 \mu \mathrm{mol}$ of ABTS per minute.

Tyrosinase activity was estimated by following the oxidation of $2 \mathrm{mM}$ of L-dopa (L-3,4-dihydroxyphenylalanine) to dopachrome (2-carboxy-2,3-dihydroindole-5,6-quinone) at $475 \mathrm{~nm}\left(\varepsilon=37000 \mathrm{M}^{-1} \mathrm{~cm}^{-1}\right)$ [54].

Peroxidase activity was determined by monitoring the oxidation of ABTS in the presence of $0.1 \mathrm{mM} \mathrm{H}_{2} \mathrm{O}_{2}$ [55]. ABTS oxidation by laccase without $\mathrm{H}_{2} \mathrm{O}_{2}$ was used as a control.

Oxidation of veratryl alcohol $(0.1 \mathrm{mM})$ to veratrylaldehyde was determined as described previously [56] by observing an increase in absorbance at $310 \mathrm{~nm}$ after 4, 6 and $24 \mathrm{~h}$.

The oxidation of the selected substrates was monitored spectrophotometrically and spectrofluorometrically in $50 \mathrm{mM}$ sodium acetate buffer solution, $\mathrm{pH} 5.5$, at $25^{\circ} \mathrm{C}$. The kinetic curves were recorded at the wavelength corresponding to the maximum of absorbance. The catalytic constants were determined as described previously [57].

The decreasing fluorescence intensity during oxidation of 1-naphthol and 2-naphthol was registered at $460 \mathrm{~nm}$ when excitation was at $320 \mathrm{~nm}$ and $328 \mathrm{~nm}$, respectively. The con- 
centration of naphthols was calculated using fluorescence intensity coefficients, determined from the calibration curves.

Laccase activity at different $\mathrm{pH}$ value was determined in a $\mathrm{pH}$-range of 3.0-9.0 using a universal $60 \mathrm{mM}$ Britton-Robinson buffer [58]. ABTS, 2,6-dimethoxyphenol, catechol, $p$-phenylenediamine, syringaldazine, and myricetin were used as substrates. For determination of the $\mathrm{pH}$ stability, enzyme was incubated at different $\mathrm{pH}$ in the range of $\mathrm{pH}$ 3.0-7.0, at room temperature for $18 \mathrm{~h}$ and the residual activity was determined with ABTS as a substrate. Optimal temperature for the laccase activity was determined by measuring the activity of enzyme at $22-70{ }^{\circ} \mathrm{C}$. For determination of the thermal stability, laccase was incubated at different temperature $\left(30-70{ }^{\circ} \mathrm{C}\right)$ for $10 \mathrm{~min}$ and the residual activity was determined with ABTS as a substrate. The time-course of stability of laccase was determined by incubating the enzyme at $60{ }^{\circ} \mathrm{C}$ for $10-150 \mathrm{~min}$ and measuring the residual enzyme activity. The effect of metal salts on laccases activity was evaluated using ABTS assay and 1-25 mM of $\mathrm{CaCl}_{2}, \mathrm{CoCl}_{2}, \mathrm{CuCl}_{2}, \mathrm{KCl}, \mathrm{NaCl}, \mathrm{MgCl}_{2}, \mathrm{MnCl}_{2}, \mathrm{NiCl}_{2}, \mathrm{CdI}, \mathrm{Li}_{2} \mathrm{SO}_{4}$, $\mathrm{ZnSO}_{4}$, and $\mathrm{Pb}\left(\mathrm{CH}_{3} \mathrm{COO}\right)_{2}$.

Dye decolorization was detected by measuring the decrease of absorbance of the appropriate dye. Acid blue $45(595 \mathrm{~nm})$, Indigo carmine $(608 \mathrm{~nm})$, Nile blue A (635 nm), Methylene blue $(665 \mathrm{~nm})$, Thionine $(598 \mathrm{~nm})$, Direct blue 90 (610 nm), Meldola blue (570 nm), Azure B (648 nm), Erythrosine (524 nm), Eriochrome black T (574 nm), and Xylenol blue $(435 \mathrm{~nm})$ were incubated with laccase $(84 \mathrm{nM}$ of Bcl1) in $50 \mathrm{mM}$ sodium acetate buffer ( $\mathrm{pH} 5.5$ ) at $25^{\circ} \mathrm{C}$ for $24 \mathrm{~h}$. Samples without the enzyme were used as controls. Initial concentration of dye solutions was set at OD $0.4-0.8$ on their maximal absorbance wavelength. The relative decolorization percentage was calculated as described [59].

\section{Results}

\subsection{The Indentification and Purification of Laccases}

A fungal strain 241 oxidizing ABTS on the solid medium was isolated from a spoiled raspberry. The fungus formed a white fuzzy mycelium, produced black resting structures (sclerotia) and branching tree-like conidiophores with conidia after growth on malt extract agar medium at $20{ }^{\circ} \mathrm{C}$ for one week. The isolate was identified as Botrytis cinerea, based on morphology and sequences of $18 \mathrm{~S}$ rRNA and internal transcribed spacer (ITS).

An analysis of extracellular enzymes showed that $B$. cinerea 241 secreted two different laccases into the media. The enzymes were assigned as $\mathrm{Bcl} 1$ and $\mathrm{Bcl}$. Both laccases were produced irrespective of the composition of used media, but in different quantities. Bcl1 was most efficiently produced in the medium SSL1 without additional salts and at lower copper concentration $(1.5 \mathrm{mM})$. On the contrary, production of $\mathrm{Bcl} 2$ was increased in the medium SSL2 supplemented with potassium phosphate $\left(20 \mathrm{~g} \mathrm{~L}^{-1}\right)$ and copper $(6 \mathrm{mM})$. The highest laccase activity was detected after seven days of growth (four days of preculture and three days of culture) and then decreased in both media studied. The laccases Bcl1 and Bcl2 in SSL1 and SSL2 media reached a maximum activity of $168 \mathrm{U} \mathrm{L}^{-1}$ and $4333 \mathrm{U} \mathrm{L}^{-1}$, respectively.

Two different schemes were applied for purification of Bcl1 and Bcl2 (Supplementary Table S1). Under optimal growth conditions, production of Bcl1 was ten times lower than Bcl2- $-0.7 \mathrm{mg} \mathrm{L}^{-1}$ and $7 \mathrm{mg} \mathrm{L}^{-1}$, respectively. The specific activity of the purified enzyme with ABTS was 76 and $147 \mathrm{U} \mathrm{mg}^{-1}$ of protein for Bcl1 and Bcl2, respectively.

The solution of the purified Bcl1 had a light-yellow color and no peak near the $600 \mathrm{~nm}$ in the UV-VIS spectrum. A shoulder at around $330 \mathrm{~nm}$ in this spectrum was also detected for Bcl1 suggesting the presence of a T3 copper site. The laccase Bcl2 exhibited a typical blue color of copper oxidases and an absorbance peak at $610 \mathrm{~nm}$ (Figure 1). 

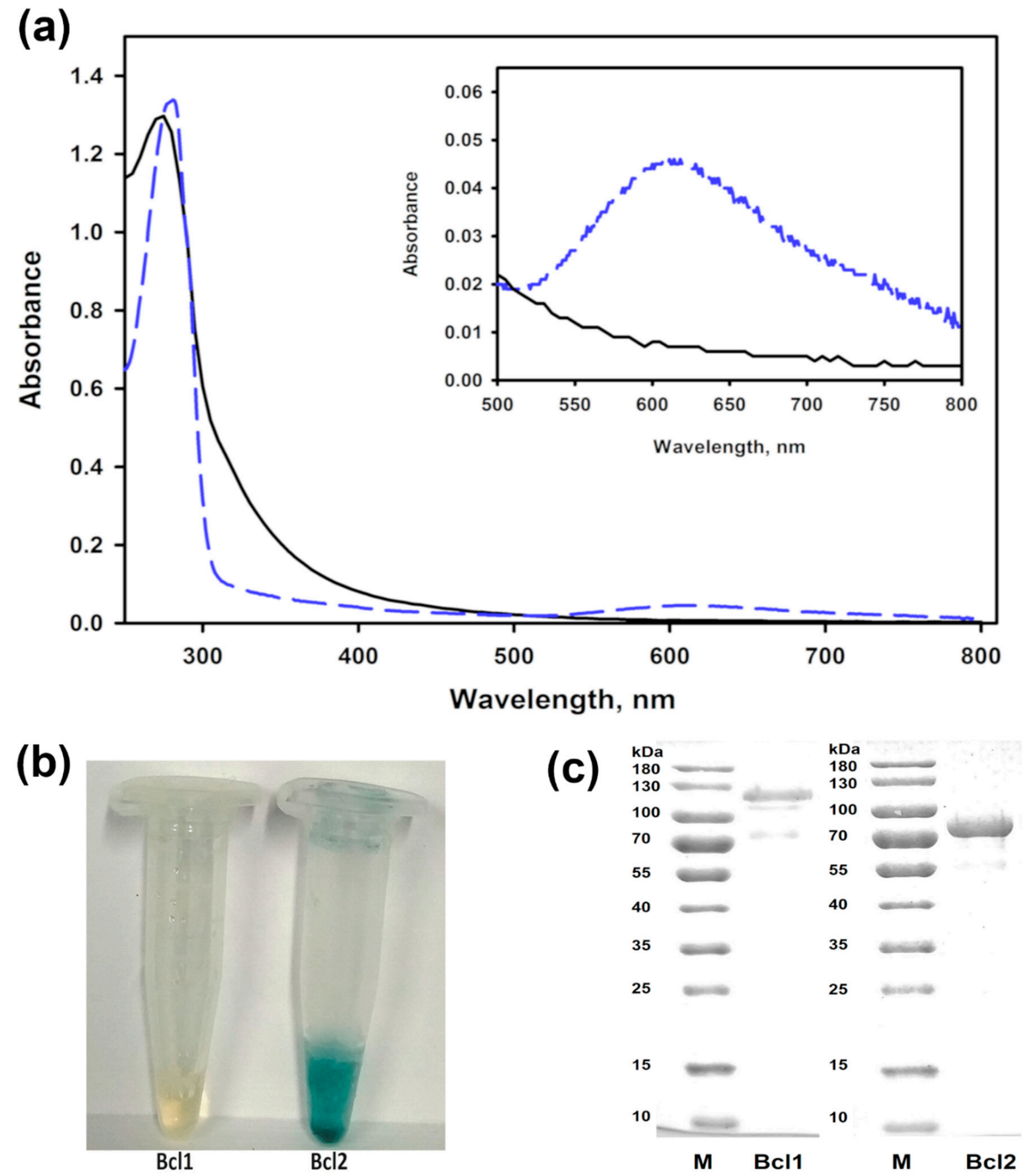

Figure 1. The properties of laccases Bcl1 and Bcl2. (a) The UV-VIS spectrum of the purified Botrytis cinerea 241 laccase Bcl1 (black solid line) and Bcl2 (blue dashed line). (b) The samples of the purified enzymes. (c) SDS-PAGE analysis of the purified proteins. $\mathrm{M}-$ molecular mass marker.

The molecular mass determined by SDS-PAGE, was $110 \pm 10 \mathrm{kDa}$ and $81 \pm 5 \mathrm{kDa}$ for $\mathrm{Bcl} 1$ and $\mathrm{Bcl} 2$, accordingly. The molecular mass of $\mathrm{Bcl} 1$ determined by a size exclusion chromatography was $186 \pm 15 \mathrm{kDa}$ (Figure S1), showing that the Bcl1 was likely a homodimer. Deglycosylation of Bcl1 reduced the activity of enzyme by $50 \%$, and the molecular mass from $110 \mathrm{kDa}$ to $104 \mathrm{kDa}$ (Figure S2). 


\title{
3.2. The Identification of the Bcl1 Encoding Gene
}

For further analysis, the protein band corresponding to the Bcl1 laccase was cut from polyacrylamide gel and, after hydrolysis with trypsin, the formed peptides were analyzed by MS/MS. In total seven peptides were obtained and covered approximately $42 \%$ of sequence of the Bclcc7 laccase from Botrytis cinerea strain B05.10 (accession number NCBI XP_001551072.1). Based on the detected peptides and the homologous gene sequence, primers were synthesized and used for the cloning of the Bcl1 laccase encoding gene from Botrytis cinerea 241. Both the genomic DNA and first-strand cDNA reverse transcribed from mRNA were used for amplification of the desired gene. Two fragments consisted of $2167 \mathrm{bp}$ and 2052 bp were obtained using genomic DNA and cDNA as matrices, respectively. An analysis of the nucleotide sequences allowed identification the ORF encoding a polypeptide of 684 amino acid residues. Comparison of DNA- and mRNA-based sequences of the bcl1 gene indicated the presence of three exons and two introns of 54 and $59 \mathrm{bp}$ in length (accession No. MT707622). Both intron splice junctions corresponded to the GT-AG rule.

The analysis of amino acid sequence of the Bcl1 protein revealed three similar cupredoxin domains. Ten conserved His and one Cys, required to coordinate four copper atoms at the three typical $\mathrm{Cu}$ (II)-type centers, were presented in the deduced amino acid sequence of the cloned Bcl1 laccase (Figure 2).

\begin{abstract}
MKLFNILLLSSAAIGAILPAQINERDVLVKRQTVSSSKTSTSSKASSTSSKASSSTSKSTSSSTVKSSSVGSSSSKASTITSGTSTSAG TTTTLSSSSTSALSSLVADPACTNSPFTRACWGNGFSIATDFDTKNPNTGVTRKYNWEVTNTTCAPDGITRQDCMLVNGQYPGPTLYAD WGDMIQVTLKNSMP DNGTGIHWHGLRQYHTCTEDGVPGNTECPLAPGDTKTYTFQATQFGTSWYHSHYSSQYGEGMLGGIVINGPATSN YDVDLGVYTISDWYYTPVFALGERIAHSQAGPP SGDNGLINGSMVAPAGQTGGKYTTNTITAGKKYRLRLINT SVDNHFMVSWDNHAFT VITSDFVP IVPYTANW I I GIGQRYDVI ITANQTVGSYWFRAEVQNGCGTNNNNGN I KSIFTYSGAASTIPSSSATPYTGRCTDETGI I PFWDSFVPSGPLSGNVEQLNVA INIGVDASGP IVTWGINLSAI DVDWKKPILQYVLDGNNSWPASENLIELPNAAQWYYWVIQEVPGNV NGNPVS INVPHPMHLHGHDFFLLGTGVGTYNNT INGPNLDYDNPTRRDVAMLPAGGWMVLAFQTDNPGAWLMHCHIAWHVSEGLAVQFL ETKDQINAVNPISPSLTNTCNKWNAWYPSQAPYIKTDSGS
\end{abstract}

Figure 2. The amino acid sequence of the Bcl1 laccase. The peptides detected by the MS/MS are marked in bold; the amino acids involved in the coordination sites for copper of the type 1, 2 and 3 are highlighted in red; putative Asn-Xaa-Ser/Thr glycosylation sites are highlighted in blue; and the peptide of a flexible loop, homologous to the Sclerotinia sclerotiorum laccase motif containing Y65 [29], that is involved in binding of phenolic compounds, is highlighted in grey (the corresponding amino acid residue D132 in Bcl1 is underlined).

A phylogenetic analysis was carried out to study the relationship of the Bcl1 laccase and laccases from Botrytis genus as well as previously characterized yellow laccases. The analysis clearly differentiated two distinct groups containing the laccases from fungi of Basidiomycota and Ascomycota phyla (Figure 3). The internal arrangement within the Botrytis group consisted of 11 different branches. The sequence of the Bcl1 protein clustered with the sequence of Bclcc7 of Botrytis cinerea B05.10. In contrast, the yellow laccase from Sclerotinia sclerotiorum (the only one ascomycotal yellow laccase with a known sequence) formed an independent branch together with the Bclcc9 laccase from Botrytis cinerea B05.10 (Figure 3). In addition, it was found, that a sequence of a flexible loop analogous to the Sclerotinia sclerotiorum laccase motif involved in binding of phenolic compounds [29] was very conservative in the proteins forming the Bcl1 branch (Figure 3c). Moreover, this loop contained aspartic acid instead of the conserved tyrosine, found in the yellow laccase from Sclerotinia sclerotiorum and all laccases of the Bclcc9-related group of proteins (Figure 3c). 


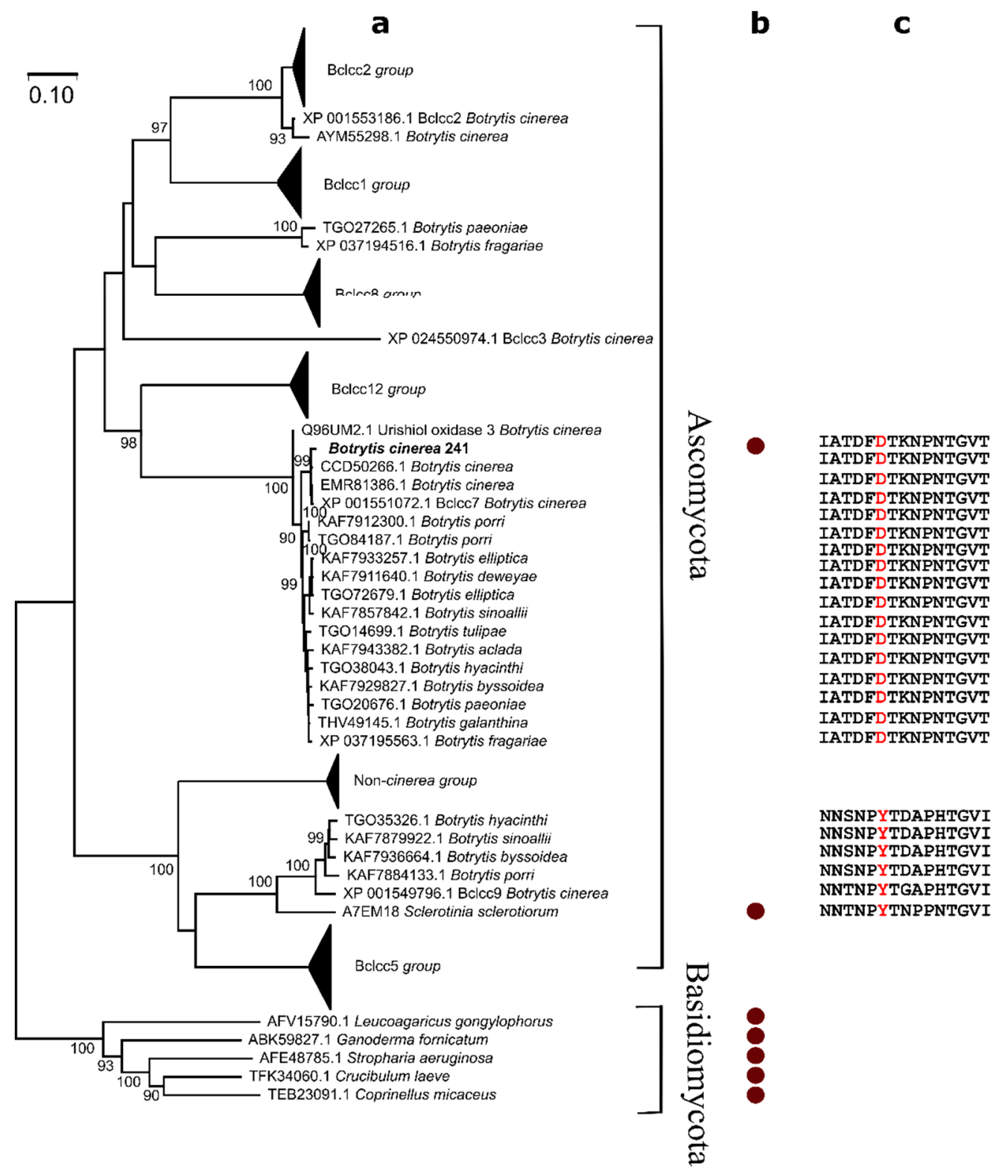

Figure 3. (a) The phylogenetic analysis of laccases encoded by Botrytis spp. The evolutionary history was inferred using the Neighbor-Joining method [60]. Scale bar: 10 substitutions site ${ }^{-1}$. The phylogenetic analysis was performed using MEGA X [51]. Bclcc numeration is based on laccases from Botrytis cinerea strain B05.10 (accession number NCBI XP_001551072.1). A yellow laccase from Botrytis cinerea 241 is marked by a bold text. The sequences used for phylogenetic analysis are listed in Table S2. (b) Known yellow laccases are included in the analysis, and are marked by circle, respectively. (c) Amino acid sequences of a flexible loop, which is homologous to the Sclerotinia sclerotiorum laccase motif containing Y65, that is involved in binding of phenolic compounds. Y65 and the corresponding amino acid residue D132 in Bcl1 are highlighted in red.

\subsection{Catalytic Properties of the Laccase Bcl1}

Bcl1 oxidized veratryl alcohol (a typical substrate for yellow laccases) (Figure S3) and most of the studied non-phenolic and phenolic compounds such as flavonoids, hydroxycinnamic and hydroxybenzoic acids. The kinetic parameters of Bcl1 are presented in Table 1. 
Table 1. Kinetic parameters of the purified laccase Bcl1.

\begin{tabular}{|c|c|c|c|}
\hline Substrate & $\mathrm{Km}, \mu \mathrm{M}$ & kcat, $\mathrm{s}^{-1}$ & kcat $/ \mathrm{Km}, \mathbf{M}^{-1} \mathbf{s}^{-1}$ \\
\hline \multicolumn{4}{|c|}{ Non-phenolic compounds } \\
\hline Potassium hexacyanoferrate (II) & $11,000 \pm 1000$ & $28.0 \pm 1$ & $2.5 \pm 0.1 \times 10^{3}$ \\
\hline p-Phenylenediamine & $150.0 \pm 20$ & $15.0 \pm 1$ & $1.0 \pm 0.02 \times 10^{5}$ \\
\hline Promazine hydrochloride & $60.0 \pm 10$ & $7.1 \pm 0.3$ & $1.2 \pm 0.1 \times 10^{5}$ \\
\hline$N, N^{\prime}$-Dimethylamine-4-(4-morpholine)benzene & $180.0 \pm 46$ & $31.0 \pm 2$ & $1.7 \pm 0.3 \times 10^{5}$ \\
\hline 2-(10H-phenoxazin-10-yl)ethanol & $40.0 \pm 7$ & $25.0 \pm 2$ & $6.3 \pm 0.3 \times 10^{5}$ \\
\hline ABTS & $13.8 \pm 0.2$ & $29.0 \pm 1$ & $2.1 \pm 0.1 \times 10^{6}$ \\
\hline 3-(10H-phenoxazin-10-yl)propanoic acid & $6.0 \pm 0.8$ & $33.0 \pm 1$ & $5.5 \pm 0.8 \times 10^{6}$ \\
\hline Syringaldazine & $0.7 \pm 0.1$ & $30.0 \pm 2$ & $4.3 \pm 0.7 \times 10^{7}$ \\
\hline \multicolumn{4}{|c|}{ Phenolic compounds } \\
\hline Methyl syringate & nd $^{1}$ & nd & $3.3 \pm 0.2 \times 10^{3}$ \\
\hline Syringic acid & $74.0 \pm 12$ & $3.4 \pm 0.5$ & $4.6 \pm 0.5 \times 10^{4}$ \\
\hline 2,6-Dimethoxyphenol & $9.0 \pm 1$ & $8.4 \pm 0.1$ & $9.3 \pm 0.1 \times 10^{4}$ \\
\hline Hydroquinone & $220.0 \pm 14$ & $21.4 \pm 0.3$ & $9.7 \pm 0.2 \times 10^{4}$ \\
\hline Ferulic acid & $51.0 \pm 3$ & $6.0 \pm 0.5$ & $1.2 \pm 0.05 \times 10^{5}$ \\
\hline Catechol & $70.0 \pm 4$ & $28.0 \pm 1$ & $4.0 \pm 0.2 \times 10^{5}$ \\
\hline Gallic acid & $27.0 \pm 8$ & $20.0 \pm 3$ & $7.4 \pm 2 \times 10^{5}$ \\
\hline Caffeic acid & $15.0 \pm 1$ & $13.0 \pm 1$ & $8.7 \pm 2 \times 10^{5}$ \\
\hline Synapic acid & $60.0 \pm 10$ & $100.0 \pm 10$ & $1.7 \pm 0.2 \times 10^{6}$ \\
\hline Quercetin & $3.7 \pm 0.8$ & $6.7 \pm 0.4$ & $1.8 \pm 0.3 \times 10^{6}$ \\
\hline Kaempferol & $8.6 \pm 0.1$ & $17.0 \pm 1$ & $2.0 \pm 0.4 \times 10^{6}$ \\
\hline Chlorogenic acid & $2.0 \pm 0.4$ & $10.0 \pm 1$ & $5.0 \pm 1.0 \times 10^{6}$ \\
\hline Fisetin & $1.5 \pm 0.1$ & $7.8 \pm 0.3$ & $5.2 \pm 0.9 \times 10^{6}$ \\
\hline 1-Naphthol & $20.0 \pm 7.0$ & $440.0 \pm 20.0$ & $2.2 \pm 0.1 \times 10^{7}$ \\
\hline Myricetin & $0.7 \pm 0.1$ & $17.0 \pm 1.0$ & $2.4 \pm 0.4 \times 10^{7}$ \\
\hline
\end{tabular}

1 -not determined. $\mathrm{Km}$ and Vmax constants cannot be determined because a linear dependence on the substrate concentration was obtained. That making it possible to calculate only one parameter $(\mathrm{kcat} / \mathrm{Km}=\mathrm{Vo} /[\mathrm{S}][\mathrm{E}]=$ slope $/[\mathrm{E}])$.

In addition, Bcl1 was able to oxidize nine structurally different dyes including phenothiazines and indigoids without the presence of any redox mediator (Figure 4). However, Bcl1 did not oxidized vanillin, 2-naphthol, galangin, cinnamic, vanillic, $m-, o-, p$-coumaric acids, and tyrosine. Moreover, Bcl1 was not active towards hydrogen peroxide.
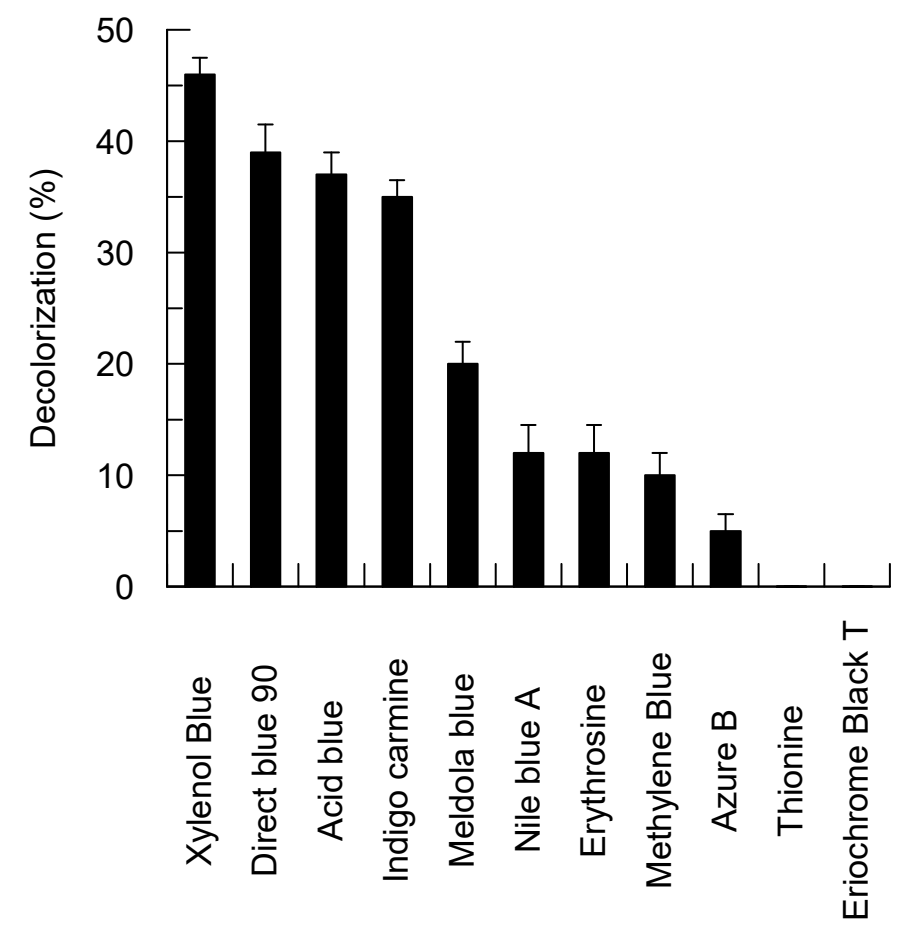

Figure 4. Decolorization of the synthetic dyes by the Bcl1 laccase. 
The optimum temperature for Bcl1 activity was identified as $60{ }^{\circ} \mathrm{C}$ (Figure 5a). The enzyme was stable at $30-55^{\circ} \mathrm{C}$, half of the activity was lost after incubation for $10 \mathrm{~min}$ and $60 \mathrm{~min}$ at $70^{\circ} \mathrm{C}$ and at $60^{\circ} \mathrm{C}$, respectively (Figure $5 \mathrm{~b}, \mathrm{c}$ ). However, approximately $60 \%$ of activity could be detected after 30 days of storage at $4{ }^{\circ} \mathrm{C}$ and $22^{\circ} \mathrm{C}$.
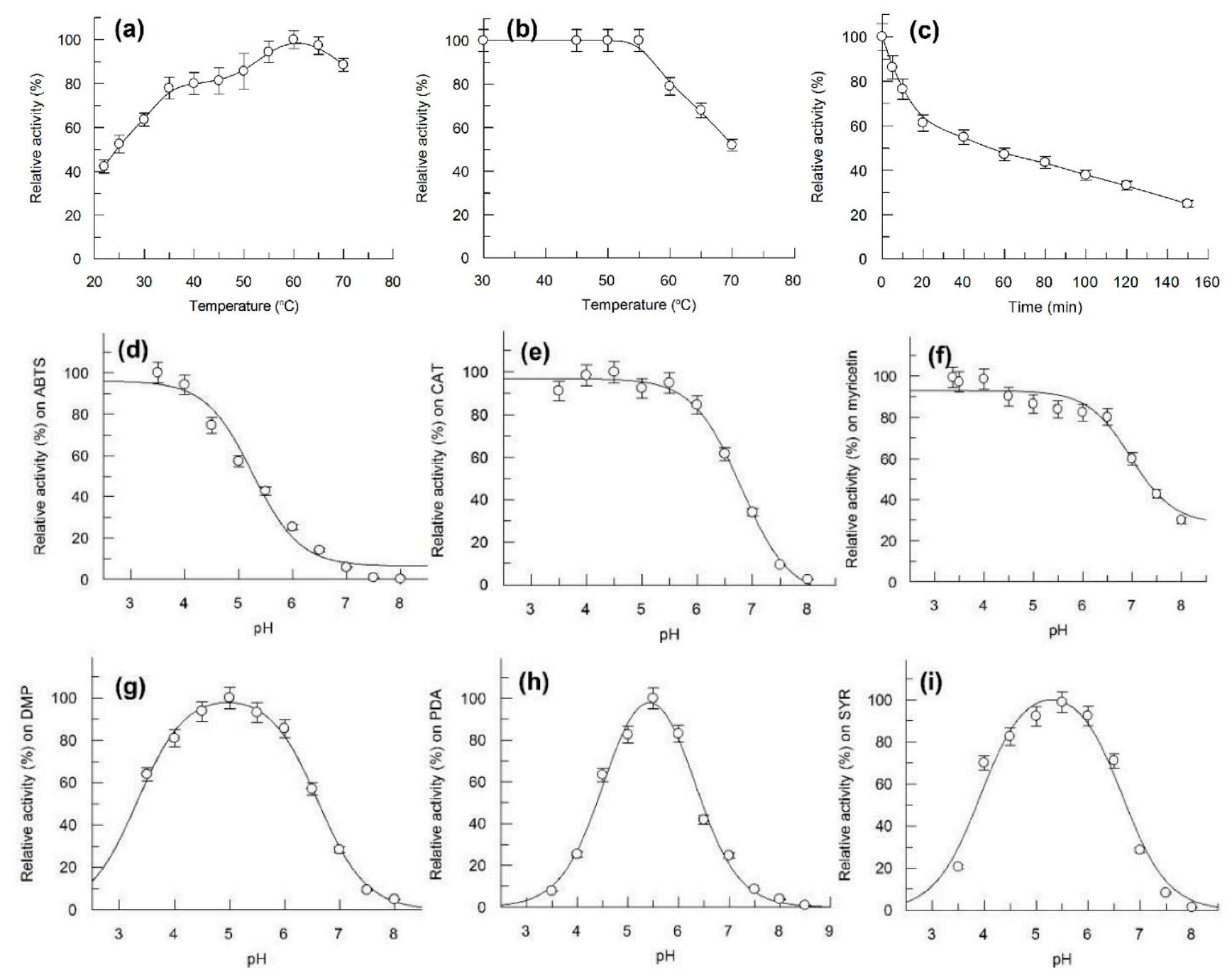

Figure 5. Effect of temperature on activity and stability of Bcl1 laccase and effect of $\mathrm{pH}$ on Bcl1 laccase activity. (a) activity of Bcl1 at different temperatures; (b) residual activity of Bcl1 incubated for $10 \mathrm{~min}$ at different temperature; (c) residual activity of Bcl1 at $60{ }^{\circ} \mathrm{C}$, incubated for 0-140 min. (d-i) activity of Bcl1 at different pH; (d) ABTS, (e) catechol (CAT), (f) myricetin, (g) 2,6-dimethoxyphenol (DMP), (h) p-phenylenediamine (PDA) and (i) syringaldazine (SYR) were used as substrates in $60 \mathrm{mM}$ Britton-Robinson buffer.

Bcl1 was stable between $\mathrm{pH} 3.0-7.0$ and showed a full activity towards ABTS for $18 \mathrm{~h}$ (data not shown). Bcl1 was active at an acidic $\mathrm{pH}$ on ABTS, catechol, and myricetin, activity decreased with increasing $\mathrm{pH}$. The enzyme activity decreased at $\mathrm{pH}$ values below 4 or above 6 on 2,6-dimethoxyphenol, $p$-phenylenediamine and syringaldazine. (Figure 5). No activity was detected above $\mathrm{pH} 8.0$.

The Bcl1 laccase demonstrated a high tolerance towards ionic strength of buffer ( $\mathrm{I}_{50}-$ $1.6 \mathrm{M} \mathrm{NaCl}$ ) and showed slightly reduced activity in the presence of various cations (up to $25 \mathrm{mM}$ ) (Figure S4), but the enzymatic activity was completely inhibited by sodium azide. 


\section{Discussion}

Depending on the growth conditions, Botrytis cinerea 241 strain produces two different laccases (Bcl1 and $\mathrm{Bcl} 2$ ). Production of more than one laccase by the same fungal strain is typical and has been reported previously [33,61]. Laccase isoenzymes have been found to originate from the same or different genes [62]. For example, in total, 17 laccase encoding genes have been identified in Coprinopsis cinerea, and at least nine of them are functional products [63]. An analysis of Botrytis cinerea B05.10 genome revealed 15 putative laccase genes [40]. One of the identified and purified enzymes in this work-Bcl1-shows a UV-VIS spectrum related to yellow laccases. To our best knowledge, only two yellow laccases from the Ascomycota phylum have been described previously-one from Gaeumannomyces graminis [64] and another from Sclerotinia sclerotiorum [29]. Furthermore, an amino acid sequence is available for the protein from Sclerotinia sclerotiorum only, hence, the Bcl1 protein has been chosen for detailed studies.

The molecular masses of the previously characterized blue laccases from Botrytis spp. varies from $60 \mathrm{kDa}$ to $100 \mathrm{kDa}[33-35,65]$. The molecular mass of the Bcl1 protein determined by SDS-PAGE is $110 \mathrm{kDa}$, however, the theoretical mass based on amino acid sequence is $73.4 \mathrm{kDa}$ only. By this feature, $\mathrm{Bcl} 1$ is the most similar to Botrytis aclada laccase [65], that migrates in the SDS-PAGE as $100 \mathrm{kDa}$ protein, although the theoretical molecular mass is $61 \mathrm{kDa}$; in contrast to the monomeric Botrytis aclada laccase, the Bcl1 enzyme is a homodimer. It can be proposed that a $\sim 37 \mathrm{kDa}$ difference in molecular masses is due to glycosylation of Bcl1. The sequence analysis according [66] shows seven potential $\mathrm{N}$-glycosylation sites (Asn-Xxx-Ser/Thr) in Bcl1, at positions 150, 194, 308, 339, 484, 565, and 577 of the deduced protein (Figure 2). However, deglycosylation of the purified protein reduces the molecular mass of the treated protein by $\sim 6 \mathrm{kDa}$ only (Figure S2). Hence, other reasons such as an unsuitable substrate specificity of the endoglycosidase $\mathrm{H}$ or an unknown post-synthetic modification take place.

The sequence of Bcl1 is highly similar (differs by five amino acid residues only) to the Bclcc7 protein from Botrytis cinerea B05.10. According to the published data, the bclcc7 gene is functional and the corresponding laccase has been detected in the vineyards and botrytized wines [36,38,67], however, the Bclcc7 enzyme has not been purified and characterized previously. In addition, a phylogenetic analysis shows, that Bcl1 and Sclerotinia sclerotiorum laccase has a low similarity ( $38 \%$ of identical amino acids) and are located on two different phylogenetic branches (Figure 3). The Sclerotinia sclerotiorum laccase contains a tyrosine residue (Y65) that is covalently modified with a phenolic compound or substrate. It has been proposed that such modification is a basis for the yellow color of the enzyme [29]. However, the appropriate tyrosine is absent in the loop near the active center of Bcl1 according to the sequence analysis (Figures 2 and 3 ) and the modelling of the protein structure (Figure S5). This suggests that other mechanisms responsible for absorption quenching at $600 \mathrm{~nm}$ may take place, and additional studies are needed to elucidate how the spectral properties are determined in the Bcl1 protein.

Bcl1 shows a wide substrate specificity and is active towards various naturally occurring and synthetic non-phenolic as well as phenolic substrates. The purified Bcl1 effectively oxidizes flavonoids, such as myricetin, fisetin and chlorogenic acid. Given that Botrytis cinerea is a plant pathogen, it can be assumed that Bcl1 is involved in the neutralization of plant defense mechanisms. The kinetic parameters of Bcl1 are similar to those of yellow laccases from Trametes sp. F1635 [24] and Daedalea flavida MTCC-145 [23]. The Bcl1 laccase tolerates high concentration of $\mathrm{NaCl}$, a similar effect has been observed for laccases from Paraconiothyrium variabile [68] and Botrytis aclada [65]. From a practical point of view, such property provides strong advantages for various environmental applications. In addition, the Bcl1 laccase decolorizes different dyes without the presence of mediators. Even the hardly degradable dye Direct blue 90, whose molecule consists of eight aromatic rings, has been used by Bcl1 laccase as a substrate. The mechanism of laccase-catalyzed dye decomposition is different depending on dye structures [69-72]. For example, the anthraquinone-type dyes can be an enzyme substrate that is directly oxidized by laccase 
while decolorization of azo- (e.g., analogous to Direct blue 90) and indigo-type dyes requires involvement of some molecules-mediators [69]. In the latter case, the decolorization rate of the nonsubstrate dyes is limited by the concentration of mediating compounds rather than laccase activity in the solutions [72]. Both natural and synthetic compounds including ABTS, $p$-coumaric acid, 3-hydroxyanthranilate, 1-hydroxybenzotriazole, syringaldehyde, 2,2,6,6-tetramethylpiperidine- $N$-oxyl, and violuric acid can mediate decolorization of synthetic dyes by laccases [70,72]. It is known that yellow laccases can outperform blue laccases in the ability to oxidize some complex substrates without mediators, making them attractive biocatalysts $[30,31]$ There have been reports of substrate activation for yellow laccases. Hence, Mot et al. [29] identified a biphasic behavior in the Michaelis-Menten saturation curve of the Sclerotinia sclerotiorum yellow laccase and associated a high-affinity phase (characterized by a lower $\mathrm{Km}$ ) with the formation of an adduct of tyrosine Y65 residing in the flexible loop with the electron-donor substrate such as 2,3-dimethoxy-5methyl- $p$-benzoquinone, ABTS, and guaiacol. It has been suggested that adduct formation with a substrate enhances the catalytic properties of the yellow laccase [29]. However, due to a lack of the appropriate tyrosine residue a different mechanism should be considered in the case of the Bcl1 laccase.

\section{Conclusions}

In conclusion, the yellow laccase Bcl1 described in this work is phylogenetically distinct from other known yellow laccases. High thermostability, high salt tolerance, broad substrate specificity, and the ability to decolorize dyes without the mediators suggest that the Bcl1 laccase is a potential enzyme for different industrial applications.

Supplementary Materials: The following are available online at https: / www.mdpi.com/2309-6 08X/7/2/143/s1, Figure S1: Analytical gel filtration chromatography of Bcl1 and Bcl2, Figure S2: Deglycosylation of Bcl1, Figure S3: Oxidation of veratryl alcohol by the Bcl1 and Bcl2 laccase, Figure S4: Effect of metal ions on the Bcl1 activity, Figure S5: Comparison of 3D models of the laccases from Botrytis cinerea 241 and Sclerotinia sclerotiorum, Table S1: Purification of laccases Bcl1 and Bcl2 from a $3 \mathrm{~L}$ of culture, Table S2: The list of amino acid sequences used for the phylogenetic analysis.

Author Contributions: I.R., R.V., R.M. (Rita Meškienè), R.M. (Rolandas Meškys) and V.Č. conceived and designed the experiments. I.R., R.V., R.M. (Rita Meškienè) and V.Č. performed the experiments. I.R., R.V., R.M. (Rolandas Meškys) and V.Č. analyzed the data. R.V. and R.M. (Rolandas Meškys) contributed reagents/materials/analysis tools. I.R., R.V., R.M. (Rolandas Meškys) and V.Č. wrote the manuscript. R.M. (Rolandas Meškys) and V.Č. revised and approved the final version of the paper. All authors have read and agreed to the published version of the manuscript.

Funding: This research was funded by European Regional Development Fund (project No. 01.2.2 -LMT-K-718-03-0082) under grant agreement with the Research Council of Lithuania (LMTLT).

Institutional Review Board Statement: Not applicable.

Informed Consent Statement: Not applicable.

Data Availability Statement: Data are contained within the article or Supplementary Materials.

Acknowledgments: We thank L. Marcinkeviciene for assistance with purification of laccases. We are grateful to M. Valius for help with MS/MS analysis.

Conflicts of Interest: The authors declare no conflict of interest.

\section{References}

1. Baldrian, P. Fungal laccases-occurrence and properties. FEMS Microbiol. Rev. 2006, 30, 215-242. [CrossRef] [PubMed]

2. Janusz, G.; Pawlik, A.; Świderska-Burek, U.; Polak, J.; Sulej, J.; Jarosz-Wilkołazka, A.; Paszczyński, A. Laccase properties, physiological functions, and evolution. Int. J. Mol. Sci. 2020, 21, 966. [CrossRef]

3. Canas, A.I.; Camarero, S. Laccases and their natural mediators: Biotechnological tools for sustainable eco-friendly processes. Biotechnol. Adv. 2010, 28, 694-705. [CrossRef]

4. Romero-Guido, C.; Baez, A.; Torres, E. Dioxygen activation by laccases: Green chemistry for fine chemical synthesis. Catalysts 2018, 8, 223. [CrossRef] 
5. Zerva, A.; Simić, S.; Topakas, E.; Nikodinovic-Runic, J. Applications of microbial laccases: Patent review of the past decade (2009-2019). Catalysts 2019, 9, 1023. [CrossRef]

6. Marcinkevičiene, L.; Vidžiunaite, R.; Tauraite, D.; Rutkiene, R.; Bachmatova, I.; Morkunas, M.; Razumiene, J.; Časaite, V.; Meškiene, R.; Kulys, J.; et al. Characterization of laccase from Coriolopsis byrsina GRB13 and application of the enzyme for synthesis of redox mediators. Chemija 2013, 24, 48-58.

7. Laurinavičius, V.; Kurtinaitienė, B.; Liauksminas, V.; Jankauskaitè, A.; Šimkus, R.; Meškys, R.; Boguslavsky, L.; Skotheim, T.; Tanenbaum, S. Reagentless biosensor based on PQQ-dependent glucose dehydrogenase and partially hydrolyzed polyarbutin. Talanta 2000, 52, 485-493. [CrossRef]

8. Dagys, M.; Laurynenas, A.; Ratautas, D.; Kulys, J.; Vidžiunaite, R.; Talaikis, M.; Niaura, G.; Marcinkevičiene, L.; Meškys, R.; Shleev, S. Oxygen electroreduction catalysed by laccase wired to gold nanoparticles via the trinuclear copper cluster. Energy Environ. Sci. 2017, 10, 498-502. [CrossRef]

9. Ratautas, D.; Ramonas, E.; Marcinkevičienė, L.; Meškys, R.; Kulys, J. Wiring gold nanoparticles and redox enzymes: A selfsufficient nanocatalyst for the direct oxidation of carbohydrates with molecular oxygen. ChemCatChem 2018, 10, 971-974. [CrossRef]

10. Munk, L.; Sitarz, A.K.; Kalyani, D.C.; Mikkelsen, J.D.; Meyer, A.S. Can laccases catalyze bond cleavage in lignin? Biotechnol. Adv. 2015, 33, 13-24. [CrossRef] [PubMed]

11. Arregui, L.; Ayala, M.; Gómez-Gil, X.; Gutiérrez-Soto, G.; Hernández-Luna, C.E.; de los Santos, M.H.; Levin, L.; Rojo-Domínguez, A.; Romero-Martínez, D.; Saparrat, M.C.N.; et al. Laccases: Structure, function, and potential application in water bioremediation. Microb. Cell Fact. 2019, 18, 200. [CrossRef]

12. Bassanini, I.; Ferrandi, E.E.; Riva, S.; Monti, D. Biocatalysis with laccases: An updated overview. Catalysts 2021, 11, 26. [CrossRef]

13. Giardina, P.; Faraco, V.; Pezzella, C.; Piscitelli, A.; Vanhulle, S.; Sannia, G. Laccases: A never-ending story. Cell. Mol. Life Sci. 2010, 67, 369-385. [CrossRef] [PubMed]

14. Solomon, E.; Heppner, D.; Johnston, E.; Ginsbach, J.; Cirera, J.; Qayyum, M.; Kieber-Emmons, M.; Kjaergaard, C.; Hadt, R.; Li, T. Copper active sites in biology. Chem. Rev. 2014, 114, 3659-3853. [CrossRef]

15. Dwivedi, U.N.; Singh, P.; Pandey, V.P.; Kumar, A. Structure-function relationship among bacterial, fungal and plant laccases. J. Mol. Catal. B Enzym. 2011, 68, 117-128. [CrossRef]

16. Rivera-Hoyos, C.M.; Morales-Álvarez, E.D.; Poutou-Piñales, R.A.; Pedroza-Rodríguez, A.M.; RodrÍguez-Vázquez, R.; DelgadoBoada, J.M. Fungal laccases. Fungal Biol. Rev. 2013, 27, 67-82. [CrossRef]

17. Komori, H.; Higuchi, Y. Structural insights into the O-2 reduction mechanism of multicopper oxidase. J. Biochem. 2015, 158, 293-298. [CrossRef]

18. Leontievsky, A.A.; Vares, T.; Lankinen, P.; Shergill, J.K.; Pozdnyakova, N.N.; Myasoedova, N.M.; Kalkkinen, N.; Golovleva, L.A.; Cammack, R.; Thurston, C.F.; et al. Blue and yellow laccases of ligninolytic fungi. FEMS Microbiol. Lett. 1997, 156, 9-14. [CrossRef]

19. Daroch, M.; Houghton, C.A.; Moore, J.K.; Wilkinson, M.C.; Carnell, A.J.; Bates, A.D.; Iwanejko, L.A. Glycosylated yellow laccases of the basidiomycete Stropharia aeruginosa. Enzyme Microb. Technol. 2014, 58-59, 1-7. [CrossRef]

20. Huang, W.T.; Tai, R.; Hseu, R.S.; Huang, C.T. Overexpression and characterization of a thermostable, pH-stable and organic solvent-tolerant Ganoderma fornicatum laccase in Pichia pastoris. Process Biochem. 2011, 46, 1469-1474. [CrossRef]

21. Pozdnyakova, N.N.; Rodakiewicz-Nowak, J.; Turkovskaya, O.V. Catalytic properties of yellow laccase from Pleurotus ostreatus D1 J. Mol. Catal. B Enzym. 2004, 30, 19-24. [CrossRef]

22. Ning, Y.J.; Wang, S.S.; Chen, Q.J.; Ling, Z.R.; Wang, S.N.; Wang, W.P.; Zhang, G.Q.; Zhu, M.J. An extracellular yellow laccase with potent dye decolorizing ability from the fungus Leucoagaricus naucinus LAC-04. Int. J. Biol. Macromol. 2016, 93, 837-842. [CrossRef] [PubMed]

23. Sharma, M.; Chaurasia, P.K.; Yadav, A.; Yadav, R.S.S.; Yadava, S.; Yadav, K.D.S. Purification and characterization of a thermally stable yellow laccase from Daedalea flavida MTCC-145 with higher catalytic performance towards selective synthesis of substituted benzaldehydes. Russ. J. Bioorg. Chem. 2016, 42, 59-68. [CrossRef]

24. Wang, S.N.; Chen, Q.J.; Zhu, M.J.; Xue, F.Y.; Li, W.C.; Zhao, T.J.; Li, G.D.; Zhang, G.Q. An extracellular yellow laccase from white rot fungus Trametes sp. F1635 and its mediator systems for dye decolorization. Biochimie 2018, 148, 46-54. [CrossRef] [PubMed]

25. Moț, A.C.; Pârvu, M.; Damian, G.; Irimie, F.D.; Darula, Z.; Medzihradszky, K.F.; Brem, B.; Silaghi-Dumitrescu, R. A “yellow” laccase with "blue" spectroscopic features, from Sclerotinia sclerotiorum. Process Biochem. 2012, 47, 968-975. [CrossRef]

26. Zhao, D.; Zhang, X.; Cui, D.; Zhao, M. Characterisation of a novel white laccase from the deuteromycete fungus Myrothecium verrucaria NF-05 and its decolourisation of dyes. PLoS ONE 2012, 7, e38817. [CrossRef]

27. Palmieri, G.; Giardina, P.; Bianco, C.; Scaloni, A.; Capasso, A.; Sannia, G. A novel white laccase from Pleurotus ostreatus. J. Biol. Chem. 1997, 272, 31301-31307. [CrossRef] [PubMed]

28. Mate, D.M.; Garcia-Ruiz, E.; Camarero, S.; Shubin, V.V.; Falk, M.; Shleev, S.; Ballesteros, A.O.; Alcalde, M. Switching from blue to yellow: Altering the spectral properties of a high redox potential laccase by directed evolution. Biocatal. Biotransform. 2013, 31, 8-21. [CrossRef]

29. Mot, A.C.; Coman, C.; Hadade, N.; Damian, G.; Silaghi-Dumitrescu, R.; Heering, H. "Yellow" laccase from Sclerotinia sclerotiorum is a blue laccase that enhances its substrate affinity by forming a reversible tyrosyl-product adduct. PLoS ONE 2020, 15, e0225530. [CrossRef] 
30. Murugesan, K.; Nam, I.H.; Kim, Y.M.; Chang, Y.S. Decolorization of reactive dyes by a thermostable laccase produced by Ganoderma lucidum in solid state culture. Enzyme Microb. Technol. 2007, 40, 1662-1672. [CrossRef]

31. Murugesan, K.; Yang, I.H.; Kim, Y.M.; Jeon, J.R.; Chang, Y.S. Enhanced transformation of malachite green by laccase of Ganoderma lucidum in the presence of natural phenolic compounds. Appl. Microbiol. Biotechnol. 2009, 82, 341-350. [CrossRef] [PubMed]

32. Mayer, A.M.; Marbach, I.; Marbach, A.; Sharon, A. Amino acid composition and molecular weight of Botrytis cinerea laccase. Phytochemistry 1977, 16, 1051-1052. [CrossRef]

33. Marbach, I.; Harel, E.; Mayer, A.M. Pectin, a second inducer for laccase production by Botrytis cinerea. Phytochemistry 1985, 24, 2559-2561. [CrossRef]

34. Zouari, N.; Romette, J.L.; Thomas, D. Purification and properties of two laccase isoenzymes produced by Botrytis cinerea. Appl. Biochem. Biotechnol. 1987, 15, 213-225. [CrossRef]

35. Slomczynski, D.; Nakas, J.P.; Tanenbaum, S.W. Production and characterization of laccase from Botrytis cinerea 61-34. Appl. Environ. Microbiol. 1995, 61, 907-912. [CrossRef] [PubMed]

36. Schouten, A.; Wagemakers, L.; Stefanato, F.L.; van der Kaaij, R.M.; van Kan, J.A.L. Resveratrol acts as a natural profungicide and induces self-intoxication by a specific laccase. Mol. Microbiol. 2002, 43, 883-894. [CrossRef]

37. Claus, H.; Sabel, A.; König, H. Wine phenols and laccase: An ambivalent relationship. In Wine, Phenolic Composition, Classification and Health Benefits; Rayess, Y.E., Ed.; Nova Publishers: New York, NY, USA, 2014; pp. 155-185.

38. Quijada-Morin, N.; Garcia, F.; Lambert, K.; Walker, A.S.; Tiers, L.; Viaud, M.; Sauvage, F.X.; Hirtz, C.; Saucier, C. Strain effect on extracellular laccase activities from Botrytis cinerea. Aust. J. Grape Wine Res. 2018, 24, 241-251. [CrossRef]

39. Amselem, J.; Cuomo, C.A.; van Kan, J.A.; Viaud, M.; Benito, E.P.; Couloux, A.; Coutinho, P.M.; de Vries, R.P.; Dyer, P.S.; Fillinger, S.; et al. Genomic analysis of the necrotrophic fungal pathogens Sclerotinia sclerotiorum and Botrytis cinerea. PLoS Genet. 2011, 7, e1002230. [CrossRef]

40. Van Kan, J.A.L.; Stassen, J.H.M.; Mosbach, A.; Van der Lee, T.A.J.; Faino, L.; Farmer, A.D.; Papasotiriou, D.G.; Zhou, S.G.; Seidl, M.F.; Cottam, E.; et al. A gapless genome sequence of the fungus Botrytis cinerea. Mol. Plant Pathol. 2017, 18, 75-89. [CrossRef]

41. Bar Nun, N.; Tal Lev, A.; Harel, E.; Mayer, A.M. Repression of laccase formation in Botrytis cinerea and its possible relation to phytopathogenicity. Phytochemistry 1988, 27, 2505-2509. [CrossRef]

42. Mayer, A.M.; Staples, R.C. Laccase: New functions for an old enzyme. Phytochemistry 2002, 60, 551-565. [CrossRef]

43. Mayer, A.M. Polyphenol oxidases in plants and fungi: Going places? A review. Phytochemistry 2006, 67, 2318-2331. [CrossRef]

44. Kulys, J.; Vidziunaite, R.; Janciene, R.; Palaima, A. Spectroelectrochemical study of N-substituted phenoxazines as electrochemical labels of biomolecules. Electroanalysis 2006, 18, 1771-1777. [CrossRef]

45. Lowry, O.H.; Rosebrough, N.J.; Farr, L.A.; Randall, R.J. Protein measurement with the Folin phenol reagent. J. Biol. Chem. 1951, 193, 265-275. [CrossRef]

46. Hellman, U.; Wernstedt, C.; Góñez, J.; Heldin, C.H. Improvement of an "In-Gel” digestion procedure for the micropreparation of internal protein fragments for amino acid sequencing. Anal. Biochem. 1995, 224, 451-455. [CrossRef] [PubMed]

47. Kutanovas, S.; Stankeviciute, J.; Urbelis, G.; Tauraite, D.; Rutkiene, R.; Meskys, R. Identification and characterization of a tetramethylpyrazine catabolic pathway in Rhodococcus jostii TMP1. Appl. Environ. Microbiol. 2013, 79, 3649-3657. [CrossRef]

48. Handy, S.M.; Demir, E.; Hutchins, D.A.; Portune, K.J.; Whereat, E.B.; Hare, C.E.; Rose, J.M.; Warner, M.; Farestad, M.; Cary, S.C.; et al. Using quantitative real-time PCR to study competition and community dynamics among Delaware Inland Bays harmful algae in field and laboratory studies. Harmful Algae 2008, 7, 599-613. [CrossRef]

49. Rédou, V.; Navarri, M.; Meslet-Cladière, L.; Barbier, G.; Burgaud, G. Species richness and adaptation of marine fungi from deep-subseafloor sediments. Appl. Environ. Microbiol. 2015, 81, 3571-3583. [CrossRef]

50. Altschul, S.F.; Gish, W.; Miller, W.; Myers, E.W.; Lipman, D.J. Basic local alignment search tool. J. Mol. Biol. 1990, 215, 403-410. [CrossRef]

51. Kumar, S.; Stecher, G.; Li, M.; Knyaz, C.; Tamura, K. MEGA X: Molecular Evolutionary Genetics Analysis across computing platforms. Mol. Biol. Evol. 2018, 35, 1547-1549. [CrossRef]

52. Chen, C.-C.; Hwang, J.-K.; Yang, J.-M. (PS) ${ }^{2}$-v2: Template-based protein structure prediction server. BMC Bioinform. 2009, 10, 366. [CrossRef] [PubMed]

53. Pettersen, E.F.; Goddard, T.D.; Huang, C.C.; Couch, G.S.; Greenblatt, D.M.; Meng, E.C.; Ferrin, T.E. UCSF Chimera-a visualization system for exploratory research and analysis. J. Comput. Chem. 2004, 25, 1605-1612. [CrossRef]

54. Horowitz, N.H.; Fling, M.; Horn, G. Tyrosinase (Neurospora crassa). Meth. Enzymol. 1970, 17, 615-620. [CrossRef]

55. Heinzkill, M.; Bech, L.; Halkier, T.; Schneider, P.; Anke, T. Characterization of laccases and peroxidases from wood-rotting fungi (family Coprinaceae). Appl. Environ. Microbiol. 1998, 64, 1601-1606. [CrossRef] [PubMed]

56. Sahay, R.; Yadav, R.S.S.; Yadava, S.; Yadav, K.D.S. A laccase of Fomes durissimus MTCC-1173 and its role in the conversion of methylbenzene to benzaldehyde. Appl. Biochem. Biotechnol. 2012, 166, 563-575. [CrossRef] [PubMed]

57. Radveikienè, I.; Pilotaitè, I.; Dainytè, R.; Vidžiūnaitè, R. Biosynthesis, purification, characterization and immobilization of laccase from Lithothelium sp. Chemija 2020, 31, 178-190. [CrossRef]

58. Michałowska-Kaczmarczyk, A.M.; Michałowski, T. Dynamic buffer capacity in acid-base systems. J. Solution Chem. 2015, 44, 1256-1266. [CrossRef]

59. Abd El-Rahim, W.M.; Moawad, H.; Abdel Azeiz, A.Z.; Sadowsky, M.J. Optimization of conditions for decolorization of azo-based textile dyes by multiple fungal species. J. Biotechnol. 2017, 260, 11-17. [CrossRef] 
60. Saitou, N.; Nei, M. The neighbor-joining method: A new method for reconstructing phylogenetic trees. Mol. Biol. Evol. 1987, 4, 406-425. [CrossRef]

61. Gigi, O.; Marbach, I.; Mayer, A.M. Induction of laccase formation in Botrytis. Phytochemistry 1980, 19, 2273-2275. [CrossRef]

62. Archibald, F.S.; Bourbonnais, R.; Jurasek, L.; Paice, M.G.; Reid, I.D. Kraft pulp bleaching and delignification by Trametes versicolor. J. Biotechnol. 1997, 53, 215-236. [CrossRef]

63. Kilaru, S.; Hoegger, P.J.; Kües, U. The laccase multi-gene family in Coprinopsis cinerea has seventeen different members that divide into two distinct subfamilies. Curr. Genet. 2006, 50, 45-60. [CrossRef] [PubMed]

64. Edens, W.A.; Goins, T.Q.; Dooley, D.; Henson, J.M. Purification and characterization of a secreted laccase of Gaeumannomyces graminis var. tritici. Appl. Environ. Microbiol. 1999, 65, 3071-3074. [CrossRef] [PubMed]

65. Kittl, R.; Mueangtoom, K.; Gonaus, C.; Khazaneh, S.T.; Sygmund, C.; Haltrich, D.; Ludwig, R. A chloride tolerant laccase from the plant pathogen ascomycete Botrytis aclada expressed at high levels in Pichia pastoris. J. Biotechnol. 2012, 157, 304-314. [CrossRef]

66. Gavel, Y.; von Heijne, G. Sequence differences between glycosylated and non-glycosylated Asn-X-Thr/Ser acceptor sites: Implications for protein engineering. Protein Eng. Des. Sel. 1990, 3, 433-442. [CrossRef]

67. Ployon, S.; Attina, A.; Vialaret, J.; Walker, A.S.; Hirtz, C.; Saucier, C. Laccases 2 \& 3 as biomarkers of Botrytis cinerea infection in sweet white wines. Food Chem. 2020, 315, 126233. [CrossRef]

68. Forootanfar, H.; Faramarzi, M.A.; Shahverdi, A.R.; Yazdi, M.T. Purification and biochemical characterization of extracellular laccase from the ascomycete Paraconiothyrium variabile. Bioresour. Technol. 2011, 102, 1808-1814. [CrossRef]

69. Wong, Y.; Yu, J. Laccase-catalyzed decolorization of synthetic dyes. Water Res. 1999, 33, 3512-3520. [CrossRef]

70. Majeau, J.A.; Brar, S.K.; Tyagi, R.D. Laccases for removal of recalcitrant and emerging pollutants. Bioresour. Technol. 2010, 101, 2331-2350. [CrossRef] [PubMed]

71. Bilal, M.; Rasheed, T.; Nabeel, F.; Iqbal, H.M.N.; Zhao, Y. Hazardous contaminants in the environment and their laccase-assisted degradation-A review. J. Environ. Manag. 2019, 234, 253-264. [CrossRef]

72. Claus, H.; Faber, G.; König, H. Redox-mediated decolorization of synthetic dyes by fungal laccases. Appl. Microbiol. Biotechnol. 2002, 59, 672-678. [CrossRef] [PubMed] 